\title{
PENYULUHAN ARTI PENTINGNYA MERK DAGANG
}

\author{
Emaya Kurniawati ${ }^{1}$, Aprih Santoso ${ }^{2^{*}}$, Sri Yuni Widowati ${ }^{3}$ \\ 1,2,3 Fakultas Ekonomi, Universitas Semarang, Indonesia \\ ema_kurniawati@yahoo.co.id ${ }^{1}$, aprihsantoso@usm.ac.id ${ }^{2}$, sri_yuniwidowati@usm.ac.id $^{3}$
}

\begin{abstract}
ABSTRAK
Abstrak: Tujuan PKM ini adalah memberikan penyuluhan kepada pelaku usaha di Kecamatan Cepiring tentang pentingnya suatu merk bagi hasil produksi sehingga produknya lebih dikenal pasaran secara lebih luas. Adapun permasalahan utama pelaku usaha di Kecamatan Cepiring adalah ketidaktahuan mengenai arti pentingnya sebuah merk untuk suatu produk. Solusi yang ditawarkan kepada pelaku usaha di Kecamatan Cepiring adalah pemberian penyuluhan mekanisme legalitas izin usaha melalui merk. Luaran kegiatan yang ingin dicapai agar pelaku usaha di Kecamatan Cepiring dapat mengembangkan usaha disertai kelengkapan legalitas / merk, sehingga operasional usaha dapat berlangsung sesuai ketentuan yang ada, Hasil penyuluhan kepada pelaku usaha di Kecamatan Cepiring akan dapat menunjang kesuksesan usaha dan penyuluhan telah terlaksana dengan sukses. Hal ini terbukti dengan antusiasnya pelaku usaha di Kecamatan Cepiring mengikuti dan berdiskusi (termasuk proses tanya jawab).
\end{abstract}

Kata Kunci: Merk Dagang, Legalitas, UMKM.

\begin{abstract}
The purpose of this PKM is to provide counseling on the importance of a brand for the production so that the product is more widely known to the market. The main problem of SME's at Cepiring Village is ignorance about not knowing the importance of a brand for a product. The solution offered is the provision counseling the legality mechanism of business licenses. The output of the activity to be achieved so that SME's at Cepiring Village can develop the business accompanied by adequate legality of establishment, so that business operations can take place according to existing provisions, the results of the training can support the business success of business actors in the SME's at Cepiring Village and have been successfully implemented. This was proven by the enthusiasm of the trainees to follow and discuss (including the question and answer process) routinely.
\end{abstract}

Keywords: Brand, Legality, SME'S

\section{A. LATAR BELAKANG}

Kecamatan Cepiring sebagaian besar lahan pertanian yaitu lahan sawah 42,2 \% lahan bukan sawah 10,0 \% dan lahan bukan pertanian 47,7\%, terdiri dari 15 desa dengan jumlah dusun/dukuh sebanyai 40 dusun. Jumlah Rukun Warga 53 dan jumlah Rukun Tetangga 323. Jumlah penduduk tahun 2015 sebanyak 51.380 jiwa, terdiri dari 26.245 (51,08\%) laki-laki dan 25.135 (48,92 \%) perempuan. Menurut kelompok umur terbanyak 10 - 14 tahun dengan jumlah sebanyak 4.556 jiwa, sedangkan jumlah penduduk terkecil umur 75 tahun keatas yaitu 851 jiwa (Kecamatan Cepiring Dalam Angka, 2017). Sebagian besar mata pencaharian penduduknya di sektor pertanian, urutan kedua dan ketiga adalah sektor 
industri pengolahan dan sektor perdagangan, hotel dan restoran.

Dalam undang-undang nomor 20 tahun 2008 tentang Usaha Mikro, Kecil, dan Menengah dijelaskan bahwa : (a) Usaha mikro adalah usaha produktif milik orang perorangan dan/atau badan usaha perorangan yang memenuhi kriteria Usaha Mikro sebagaimana diatur dalam Undang-Undang ini. (b) Usaha Kecil adalah usaha ekonomi produktif yang berdiri sendiri, yang dilakukan oleh orang perorangan atau badan usaha yang bukan merupakan anak perusahaan atau bukan cabang perusahaan yang dimiliki, dikuasai, atau menjadi bagian baik langsung maupun tidak langsung dari Usaha Menengah atau Usaha Besar yang memenuhi kriteria Usaha Kecil sebagaimana dimaksud dalam UndangUndang ini. (c) Usaha Menengah adalah usaha ekonomi produktif yang berdiri sendiri, yang dilakukan oleh orang perorangan atau badan usaha yang bukan merupakan anak perusahaan atau cabang perusahaan yang dimiliki, dikuasai, ataupun menjadi bagian baik langsung maupun tidak langsung dengan Usaha Kecil atau Usaha Besar dengan jumlah kekayaan bersih atau hasil penjualan tahunan sebagaimana diatur dalam Undangundang ini. Usaha Mikro Kecil (UMK) di Kecamatan Cepiring berjumlah 35 usaha. Dengan telah terbentuknya kelompok usaha tersebut, diharapkan unit usaha dapat berkembang seiring dengan berkembangnya kelompok usaha tersebut. Salah satu tolok ukur berkembangnya kelompok usaha adalah adanya perkembangan omset penjualannya, yang salah satunya adalah melalui pruduk UMKM yang bermerk. Merk yaitu sebuah nama, istilah, tanda, simbol, rancangan, atau kombinasi dengan tujuan guna mengenali produk atau jasa produsen serta aagar dapat dibedakan atas produk lain. Merk dapat menyampaikan empat tingkat arti : (1) Atribut. (2) Manfaat. (3) Nilai. dan (4) Kepribadian.

Pelaku usaha UMKM Kecamatan Cepiring ternyata produknya tanpa merk, padahal sebenarnya jika dilihat dari hasil produk sendiri ternyata memiliki kelebihan yang tidak kalah enak dibanding dengan produk diluar UMKM Kecamatan Cepiring yang dijual di pasaran. Akibat tanpa merk maka masyarakat umum belum banyak yang mengenal produk UMKM Kecamatan Cepiring tersebut. Selain itu, merk juga sebagai tanda pembeda dan merk juga memiliki manfaat penting sebagai hak kepemilikan pelaku usaha pelaku usaha UMKM Kecamatan Cepiring agar merk yang mereka miliki terhindar dari penjiplakan. Manfaat inilah yang oleh pelaku usaha UMKM Kecamatan Cepiring belum ketahui sebagai legalitas merk produknya, karena berdasarkan pemahaman pelaku usaha UMKM Kecamatan Cepiring merk hanya sekedar tanda pembeda saja. Menurut hasil survei diketahui bahwa permasalahan pelaku usaha UMKM Kecamatan Cepiring belum tahu tentang cara yang harus dijalankannya untuk suatu usaha jika ingin memiliki merk sehingga akhirnya omset usahanya dapat berkembang dan pada akhirnya usahanya akan mengalami kemajuannya. Obyek pengabdian kepada masyarakat ini dilaksanakan untuk pelaku pelaku usaha UMKM Kecamatan Cepiring sebagai target program dengan tujuan agar supaya terjadi pemahaman terkait legalitas (merk). 


\section{B. METODE PELAKSANAAN}

Pada tahap awal, dilakukan survei lokasi dan identifikasi masalah dari pelaku usaha UMKM Kecamatan Cepiring terlebih dahulu oleh Tim PKM dengan tujuan agar diketahui apa yang dibutuhkan oleh pelaku usaha UMKM Kecamatan Cepiring. Pada tahap selanjutnya, pelaksanaan kegiatan PKM untuk pelaku usaha UMKM Kecamatan Cepiring mmelalui penyuluhan dengan menggunakan metode ceramah, diskusi, tanya jawab secara langsung dan contoh kasus.

\section{HASIL DAN PEMBAHASAN}

\section{Pelaksanaan PKM}

Tim PKM melakukan survei lokasi yang menjadi obyek PKM yaitu pada pelaku usaha UMKM di Kecamatan Cepiring dan melakukan indepth interview tentang rencana pelaksanaan kegiatan PKM. Pelaku usaha UMKM di Kecamatan Cepiring menetapkan waktu, tempat untuk kegiatan pengabdian kepada masyarakat dan kemudian membagikan undangan kepada pelaku usaha UMKM di Kecamatan Cepiring untuk hadir mengikutinya. Pada tahap pelaksanaan berupa penyuluhan tentang merk, yangmana penyuluhan diikuti oleh pelaku usaha UMKM Kecamatan Cepiring. Pada saat pelaksanaan PKM ini Tim PKM berbagi tugas sesuai dengan bidang keahlian ilmu masing-masing.Tim PKM melaksanakan pengabdian kepada masyarakat selama 1 hari yaitu pada : Kamis, 8 Pebruari 2018 yang diikuti sebanyak 27 orang. Peserta pelaku usaha UMKM Kecamatan Cepiring mendapat masukan dari pemateri tentang arti penting merk untuk suatu produk usaha. Kegiatan PKM inipun mendapatkan sambutan yang baik dari pelaku usaha UMKM Kecamatan Cepiring. Hal ini terlihat dari keseriusan mereka untuk ikut terlibat secara langsung dalam diskusi dan dalam menangani contoh kasus merk.

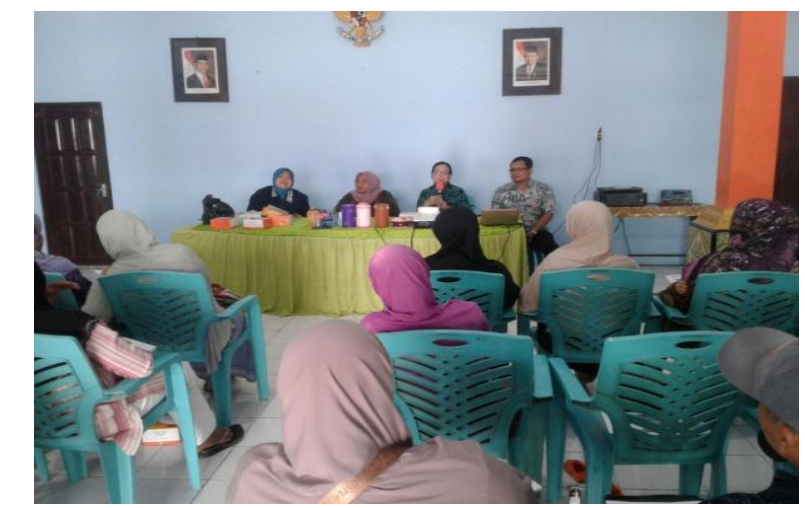

Gambar 1. Peserta Antusias Mengikuti Penyuluhan

Gambar 1 memperlihatkan bahwa pelaku usaha UMKM Kecamatan Cepiring peserta penyuluhan secara serius memperhatikan materi penyuluhan yang disampaikan oleh pemateri yaitu mengenai pengertian merk. Disamping itu pemateri dan Tim PKM yang lain juga 
memperhatikan peserta yang mengalami kesulitan untuk menjelaskannya dan memberikan pendampingan.

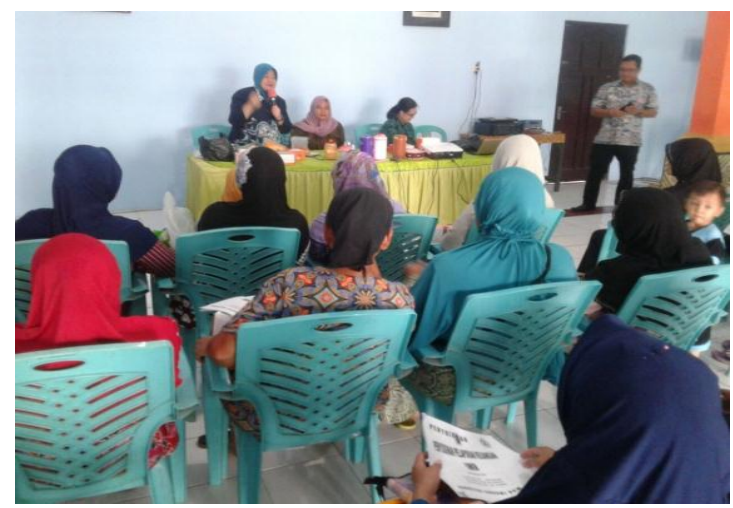

Gambar 2. Peserta Berdiskusi dan Tanya Jawab Dengan Pemateri

Gambar 2 menunjukkan bahwa pelaku usaha UMKM Kecamatan Cepiring mengikuti penyuluhan secara serius saat berdiskusi dan tanya jawab dengan pemateri yaitu mengenai cara mengurus merk.

Sesi terakhir dari kegiatan KPM beerupa penyuluhan tentang merk ini adalah foto bersama. Suasana tersebut tampak pada Gambar 3 berikut:

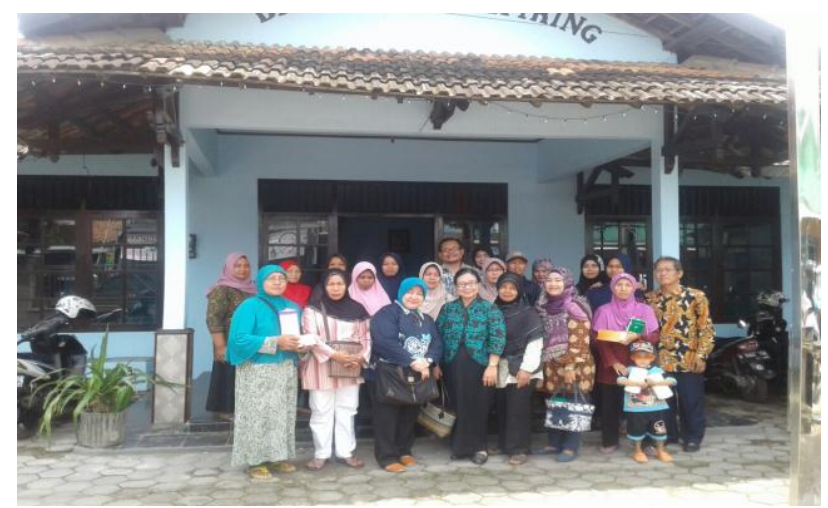

Gambar 3. Peserta foto bersama dengan Tim PKM

Gambar 3 menunjukkan bahwa peserta penyuluhan telah selesai mengikuti materi-materi penyuluhan yang disampaikan Tim PKM dalam acara berfoto bersama pemateri dan tim PKM yang lain.

\section{Monitoring}

Setelah selesainya penyuluhan kepada pelaku usaha UMKM Kecamatan Cepiring maka pada tahap selanjutnya Tim PKM melakukan monitoring dengan tujuan untuk mengetahui apakah usaha yang dijalankan pasca penyuluhan telah dilaksanakan sesuai dengan ilmu yang telah mereka terima di penyuluhan yang sudah mereka ikuti. Apabila ternyata belum sesuai dengan ilmu yang telah mereka terima di penyuluhan yang sudah mereka ikuti tersebut maka dicari alas annya mengapa dan kendala apa saja yang mereka hadapi, sehingga Tim PKM memberi solusinya. 


\section{SIMPULAN DAN SARAN}

Dari hasil kegiatan PKM tentang arti penting merk kepada pelaku usaha UMKM Kecamatan Cepiring, maka dapat disimpulkan sebagai berikut : (1) Meningkatnya pemahaman dan pengetahuan tentang pada pelaku usaha UMKM Kecamatan Cepiring. (2) Meningkatnya ketrampilan pada pelaku usaha UMKM Kecamatan Cepiring tentang Merk dan memahami kasus merk. Adapun sarannya adalah untuk lebih meningkatkan lagi ketrampilan, para peserta pelaku usaha UMKM Kecamatan Cepiring hendaknya selalu mempraktekkan hasil penyuluhan dalam pekerjaan sehari-hari agar tidak mudah lupa yang akan berakibat cepat hilangnya ketrampilan.

\section{UCAPAN TERIMA KASIH}

Tim PKM mengucapkan terima kasih kepada (1) Mitra PKM yaitu pelaku usaha UMKM Kecamatan Cepiring, dan (2) Lembaga Penelitian dan Pengabdian Masyarakat (LPPM) Universitas Semarang.

\section{DAFTAR RUJUKAN}

Amirullah. (2015). Pengantar Manajemen. MitraWacana Media, Jakarta

Ardana, Komang, Ni Wayan Mujiati, dan I Wayan Mudiartha Utama. (2012). Manajemen Sumber Daya Manusia. Graha Ilmu. Yogyakarta.

Choliq, Abdul. (2011). Pengantar Manajemen, Rafi Sarana Perkasa. Semarang.

Cici, S.I. (2015). Pengaruh Brand Origin, Brand ambassador dan Citra Merk terhadap Keputusan Pembelian sepatu Macbeth di sogo Surabaya. $e^{-}$ Jurnal Manajemen Kinerja, 1(2).

Devi, G. (2014). Pengaruh Brand ambassador terhadap Citra merk pada perusahaan Online Zalora. Jurnal Administrasi Bisnis, Universitas Telkom, 3(11).

Evelina, N. (2012). Pengaruh Citra Merk, Kualitas Produk, Harga, dan Promosi Terhadap Keputusan Pembelian Kartu Perdana Telkomflexi (Studi Kasus Pada Konsumen Telkomflexi di Kudus). Jurnal manajemen bisnis, 1-11

Hasibuan, Malaayu, S.P, (2011). Manajemen : Dasar, Pengertian, dan Masalah. Edisi Revisi. Bumi Aksara. Jakarta.

Kotler, Philip. (2010). Manajemen Pemasaran (Analisis, Perencanaan, dan Pengendalian), Terjemahan Jaka Wasana, Institut dan Pembinaan Manajemen, Jilid I, Edisi Kelima, Cetakan Ketujuh. Erlangga. Jakarta.

Undang-undang Nomor 20 tahun 2008 tentang Usaha Mikro, Kecil dan Menengah 